\title{
Growth, productive performance, and udder health of crossbred Holstein x Simmental cows and purebred Holstein cows
}

\section{Crescimento, desempenho produtivo e sanidade da glândula mamária de vacas mestiças Holandês x Simental e vacas puras Holandês}

\author{
Deise Aline Knob ${ }^{1 *}$; Dileta Regina Moro Alessio²; André Thaler Neto ${ }^{3}$; \\ Fabrício Desconsi Mozzaquatro ${ }^{4}$
}

\begin{abstract}
The crossbreeding between dairy cow breeds has been used as an alternative to improve some characteristics such as milk composition, udder health, and reproductive aspects on dairy herds. The aim was to compare growth, milk yield and composition, and mammary gland health of crossbred Holstein $\mathrm{x}$ Simmental and purebred Holstein cows. Data were gathered from a farm located in Santa Catarina state, south of Brazil. Cow growth was assessed by weighing calves and heifers monthly. Yet for milk yield and udder health, data were taken from records of the official Dairy Herd Improvement Program carried out in the evaluated farm. These data were subjected to variance analysis using the MIXED procedure of SAS statistical software. Non-linear regressions were used to adjust the data to the growth curves. The crossbred Holstein $x$ Simmental cows produced more milk than did purebreds (31.8 kg/day vs. 30.4 $\mathrm{kg} / \mathrm{day} ; \mathrm{p}<0.05)$, with higher contents of lactose ( $4.63 \%$ vs. $4.53 \%)$ and protein $(3.14 \%$ vs. $3.03 \%)$, but no differences in fat content (3.00 vs. 2.96). Purebred cows had higher somatic cell score (SCS) 4.49 vs. $2.93(\mathrm{P}<0.0001)$. Furthermore, no differences were found for the growth of calves and heifers. In conclusion, crossbred Holstein x Simmental cows have higher energy corrected milk as the Holstein ones, whit greater uncorrected milk yield only for cows with three or more lactations. Crossbreeds cows produce milk with better quality, indicated by lower SCS and higher solids content, besides showing a lower SCS and no differences regarding weight gain of calves and heifers.
\end{abstract}

Key words: Gompertz. Heterosis. Lactose content. Milk yield. Somatic cell count. Wood.

\section{Resumo}

O cruzamento entre raças leiteiras tem sido usado como alternativa para melhorar algumas características como a composição do leite, sanidade da glândula mamária e aspectos reprodutivos em rebanhos leiteiros. O objetivo foi comparar o crescimento, produção e composição do leite e sanidade da glândula mamária de vacas mestiças Holandês x Simental e vacas puras Holandês. Os dados foram obtidos em uma fazenda em Santa Catarina, sul do Brasil. Crescimento de bezerras e novilhas foi estimado pela

\footnotetext{
1 Discente, Curso de Doutorado do Programa de Pós-Graduação em Ciência Animal, Universidade do Estado de Santa Catarina, Centro de Ciências Agroveterinárias, UDESC/CAV, Lages, SC, Brasil. E-mail: deisealinek@hotmail.com

2 Dra em Ciência Animal, Lages, SC, Brasil. E-mail: alessiodrm@gmail.com

3 Prof. Titular, Departamento de Produção Animal e Alimentos, Ciência Animal, Universidade do Estado de Santa Catarina, Centro de Ciências Agroveterinárias, UDESC/CAV, Lages, SC, Brasil. E-mail: andre.thaler@udesc.br

4 Prof., Universidade Federal do Pampa, UNIPAMPA, Campus de Uruguaiana, Uruguaiana, RS, Brasil. E-mail: fabriciomozzaquatro@unipampa.edu.br

* Author for correspondence
} 
pesagem mensal dos animais. Informações sobre produção e composição do leite e sanidade de glândula mamária foram obtidos dos relatórios de controle leiteiro oficial. Os dados foram submetidos análise de variância usando o procedimento MIXED do pacote estatístico SAS. Regressões não lineares foram usadas para gerar curvas de crescimento. Vacas mestiças Holandês x Simental produziram mais leite que vacas puras Holandês $(31,8 \mathrm{~kg} / \mathrm{dia}$ vs. $30,4 \mathrm{~kg} / \mathrm{dia} ; \mathrm{p}<0,05)$, com maior teor de lactose $(4,63 \% \mathrm{vs}$. $4,53 \%)$ e proteína $(3,14 \%$ vs. $3,03 \%)$, mas sem diferença para teor de gordura $(3,00$ vs. 2,96$)$. Vacas puras Holandês apresentaram maior escore de células somáticas (ECS) 4,49 vs. 2,93 ( $\mathrm{P}<0,0001)$. Além disso, não houve diferença para crescimento de bezerras e novilhas. Conclui-se que, vacas mestiças Holandês x Simental, produziram mais leite corrigido para energia e proteína em relação as vacas Holandês, com maior produção de leite não corrigido apenas para vacas com três ou mais partos. Vacas mestiças produzem leite com mais qualidade, indicado pela baixa ECS e o maior teor de sólidos, sem diferença para crescimento de bezerras e novilhas.

Palavras-chave: Escore de células somáticas. Gompertz. Heterose. Lactose. Produção de leite. Wood.

\section{Introduction}

For several years milk yield has been the main goal in genetic improvement programs, and the Holstein has been quite a remarkable breed in such purpose (OLTENACU; BROOM, 2010). Nonetheless, some important traits such as milk composition and udder health have not received the same level of importance. As a result, unfavorable genetic correlations between some characteristics of economic importance have been adversely impaired, e.g. fat and protein contents, fertility, and somatic cell counts (SCC), which is an important indicator of udder health. Recently, more attention has been given to these aspects in genetic improvement programs, as long as they are able to promote an economic impact for farmers and the dairy industry. As an example, we can mention that a high SCC is related to milk yield reductions and adverse changes in its composition (CINAR et al., 2015).

One of the alternatives to solve the problem is the crossing between dairy breeds, being the cross between Jersey and Holstein cows one of the most popular worldwide. This cross is especially used in New Zealand, for example. The purpose of crossing is to combine positive traits from different breeds and exploit the benefits of hybrid vigor (heterosis) and complementarity. In southern Brazil, crossbreed Holstein $\mathrm{x}$ Jersey cows have been shown to be more efficient for the production of milk solids (THALER NETO et al., 2013).
In European countries, mainly in Germany, an alternative crossing widely used is between the Holstein and Simmental (dual purpose) breeds. Such cross has proved to be effective for improving milk composition, mammary gland health, fertility, body condition score, and animal longevity (SCHWAIGER, 2008; BRÄHMIG, 2011; NEMES et al., 2012; HAZEL et al., 2014).

Besides productive and mammary gland health characteristics, another important aspect on dairy farms with productive and commercial impact is the growth of calves and heifers. Growth curves allow observing the development of an animal or a group of animals and determining whether it is within the expected average range for the breed. In addition, this is an important tool for selection of highperformance animals and improvement of nutritional management. When comparing the development and weight gain of crossbred Holstein x Brown Swiss with purebred Holstein heifers, Brown et al. (2001) observed that 6-month crossbred animals were heavier; however, there were no significant differences for 14-month heifers. In the same study, the authors compared crossbred Holstein $\mathrm{x}$ Jersey and purebred Holstein animals and reported lower weights for 6- and 14-month crossbreds. A similar result was reported in Brazil for Holstein $\mathrm{x}$ Jersey heifers, which showed a lower body weight compared to purebreds Holstein (RODRIGUES et al., 2014). 
Likewise, developing curves for milk yield, composition, and SCC allows us to understand the behavior of these variables during lactation, besides being able to help in herd management decisions and animal selection.

The aim was to evaluate milk yield and composition, mammary gland health, as well as compare the growth of crossbreds Holstein $\mathrm{x}$ Simmental with purebred Holstein animals in a subtropical environment.

\section{Material and Methods}

Data were taken from a dairy farm located in Bom Retiro, state of Santa Catarina, Brazil (274' 50 “South, 49²9'21”' West, 890-m altitude). According to the Köppen classification, the local climate is classified as CFA type, which stands for a humid subtropical region (PEEL et al., 2007). In the farm, purebred Holstein and $F_{1}$ Holstein $x$ Simmental cows are raised, and the latter were originated from random crossings between purebreds Holstein cows inseminated with semen from Simmental bulls (dairy lineage of Simmental), which were selected on the basis of dairy breeding values imported from Germany. The Simmental is a dual purpose breed. The Holstein semen used to inseminate the purebred Holstein cows was imported from Canada and United States of America having a high genetic value. For both genetic groups at least 3 different bulls were used for the inseminations every year.

Cows were managed under a semi-confinement system, being maintained on pastures of oats and ryegrass in the winter and sorghum in the summer. They were also supplemented with corn silage, grass silage, and concentrate twice daily. The cows were subjected to twice-a-day milking in a fishbone parlor $(12 \times 02)$. In the farm, there were about 170 lactating cows, among which 110 were purebred Holstein and 60 were crossbred Holstein $\mathrm{x}$ Simmental $\mathrm{F}_{1}$ cows. The nutritional management as well as the environmental conditions were the same for both genetic groups. Mean Calving intervals were 381 and 445 days for the crossbreds and purebreds, respectively. Mean age at the first calving was $28.2 \pm 0.29$ months, with no difference between genetic groups (KNOB et al., 2016).

Calf and heifer growth from birth until 24 months of age was estimated monthly by thoracic perimeter measures. For that, a commercial tape for Bos taurus breeds was used, measuring the hearth girth of the animal immediately behind the forelegs. This procedure is commonly used for routine management in Brazilian dairy farms and has a high correlation with body weight (HEINRICHS et al., 1992). These measurements were performed with the animals firmly standing on four legs over a flat ground. These data were gathered from 2010 to 2013 , totaling 1,582 repeated records from 290 animals, i.e. each animal was assessed more than once.

Experimental data were analyzed by SAS software. The genetic effect on calf and heifer was tested by analysis of variance (ANOVA) as repeated measures, using the MIXED procedure of SAS. The model was composed of the variables: genetic group, year and season of birth of the animals. Growth curves were generated for the genetic groups of heifers (purebred Holstein and crossbred Holstein $\mathrm{x}$ Simmental) by nonlinear regression, using the NLIN procedure of SAS. The Gompertz function was used to find the best adjustment for the models, which is evidenced by a lower error mean square. The Gompertz model can be described as follows: $\mathrm{Y}=\mathrm{A} \exp \left[(\mathrm{B} / \mathrm{K})\left(1-\mathrm{e}^{-\mathrm{Kt}}\right)\right.$, where $\mathrm{Y}$ is the live weight; $\mathrm{A}$ is the asymptotic weight estimate; $\mathrm{B}$ is a constant of integration; $\mathrm{K}$ is maturity index (SAXTON, 2004).

Productive performance and mammary gland health were characterized monthly by records from a dairy-herd improvement program (DHI). These data were supplied by the Association of Dairy Cattle Breeders from Santa Catarina State (ACCB). Milk yield and composition data were gathered through monthly measures of milk volume, using 
a milk meter (Waikato MK5, Waikato Milking Systems NZ Ltd.), and monthly milk sampling from each lactating cow, using 40-ml bottles containing conservative bronopol After measuring milk yield, these samples were homogenized. One composite milk sample from morning and afternoon milking was taken from each cow and sent to a laboratory participating in the Milk Quality Program of Brazil, where analyses were run. All the analyses were performed using automated equipment (Soma Count FC and Dairy Spec FT Bentley ${ }^{\circledR}$ ). The somatic cell counts (SCC) was performed using flow cytometry, according to the ISO 13366-2 method. Yet the milk composition was determined by an infrared technique, according to ISO 9622 guidelines, both these methods are prescribed by the INMETRO IEC 17025:2002. Samples were recorded from 2011 to 2013 .

For statistical analyses, outliers or potential errors from milk sampling were removed by data standardization, only were used records between 8 and 305 days of lactation, milk yields between 10 and 60 liters per day, fat contents between 1.5\% and $5.6 \%$, protein content between $2.0 \%$ and $5.3 \%$, and lactose content between $3.0 \%$ and $5.2 \%$. Parity were grouped as first, second and third or more parturitions. For normality, SCC was transformed to somatic cell score (SCS) by the logarithmic scale $(\mathrm{SCCt})$, as the following function: $\mathrm{SCCt}=$ $\log 2(\mathrm{SCC} / 100)+3$. Following these restrictions, 2,797 individual milk test-day records were made available, 1,886 from purebred Holstein and 911 from crossbred Holstein x Simmental cows (a total of 301 cows). Of all available records, $34.22 \%$ comprised cows in first lactation, and $65.78 \%$ in second or later lactations.

The milk yield, composition, and SCS was estimated by submitting milk test-day data to ANOVA, including all tests as time repeated measures, using the MIXED procedure of SAS. The model was composed of the following variables: genetic group, parity, calving season and year, parity and genetic group interaction, and the linear and quadratic effect of the covariate days in milk (DIM). Before variance analysis, data were tested for normality of residuals using the Shapiro-Wilk test and for homogeneity of variances by Levene's test. Energy corrected milk yield (ECM) was obtained by the equation: $\mathrm{ECM}=(0.327 * \mathrm{MY})+(12.95 \% *$ $\mathrm{G} * \mathrm{MY} / 100)+(7.65 \% \mathrm{P} * \mathrm{MY} / 100)$; wherein: $\mathrm{MY}=$ milk yield in $\mathrm{kg} /$ day, $\mathrm{G}=$ fat percentage, and $\mathrm{P}=$ protein percentage. In addition, data from milk samples with less than 200,000 cells/ml of both genetic groups were submitted to ANOVA, with the aim of clarifying the negative effect of a high SCC on milk yield.

To demonstrate the behavior of milk yield, fat, protein and lactose contents, and SCS according to DIM, curves were generated for purebred and crossbred cows by nonlinear regression, using the NLIN procedure of SAS. When compared to other non-linear regressions, these data had a smaller error mean square, therefore, the Wood model was fitted to them. This model can be described by the equation: $\mathrm{Y}=\mathrm{At}^{\mathrm{b}} \mathrm{e}^{\text {-ct; }}$, wherein: $\mathrm{Y}=$ yield or content or SCC; A, b, and c are constants, among which A is a theoretical initial value, $b$ is the increase or decrease of the variable concerned up to a maximum or minimum peak, $\mathrm{c}=$ is the increase or decrease of the variable concerned after the maximum or minimum peak, $t$ is the time in days, and $e$ is the base of natural logarithm (SAXTON, 2004). These constants were suitable for milk yield, milk composition, and SCS.

\section{Results}

In general, crossbreds Holstein x Simmental were more productive than purebred Holstein $(p<0.05)$, as seen in Table 1. This result was accompanied by a higher performance on ECM of crossbred cows. There was an interaction between genetic group and parity $(\mathrm{p}<0.001)$ for milk yield. In this way, the genetic groups presented no difference in the first and second lactation, whereas for cows with 3 and more lactations the difference favored crossbreds (Table 2). 
Table 1. Means adjusted to the model \pm standard error (SEM) and $\mathrm{P}$ value for interaction between genetic groups (GG) and parity for milk yield, milk composition, and somatic cell score (SCS) for Holstein purebred and Holstein x Simmental crossbred cows.

\begin{tabular}{lcccc}
\hline \multirow{2}{*}{ Variable } & \multicolumn{2}{c}{ Genetic groups } & \multicolumn{2}{c}{ P Value } \\
\cline { 2 - 5 } & Holstein & Holstein x Simmental & GG & GG*Parity \\
\hline Milk yield (Kg/day) & $30.55 \pm 0.42$ & $31.95 \pm 0.60$ & 0.0432 & 0.0149 \\
Fat \% & $2.96 \pm 0.03$ & $3.00 \pm 0.04$ & 0.3860 & 0.0028 \\
Fat (Kg/day) & $0.89 \pm 0.01$ & $0.95 \pm 0.02$ & 0.0135 & 0.8626 \\
Protein \% & $3.03 \pm 0.02$ & $3.14 \pm 0.02$ & $<0.0001$ & 0.6981 \\
Protein (Kg/day) & $0.92 \pm 0.01$ & $0.99 \pm 0.02$ & 0.0003 & 0.0182 \\
Lactose \% & $4.53 \pm 0.01$ & $4.63 \pm 0.02$ & $<0.0001$ & 0.9355 \\
Lactose (Kg/day) & $1.39 \pm 0.02$ & $1.48 \pm 0.03$ & 0.0056 & 0.0179 \\
SCS & $4.46 \pm 0.13$ & $2.81 \pm 0.18$ & $<0.0001$ & 0.2988 \\
ECM (kg/day) & $28.53 \pm 0.38$ & $30.27 \pm 0.55$ & 0.0059 & 0.1414 \\
\hline
\end{tabular}

$\mathrm{ECM}=$ energy- and protein-corrected milk yield.

Table 2. Means adjusted to the model for milk yield according to genetic groups (GG) and parity.

\begin{tabular}{lccc}
\hline \multirow{2}{*}{ GG } & \multicolumn{3}{c}{ Parity } \\
\cline { 2 - 4 } & 1 & 2 & $\geq 3$ \\
\hline Holstein & $27,67 \mathrm{Ba}$ & $32,58 \mathrm{Aa}$ & $31,40 \mathrm{Ab}$ \\
Holstein x Simmental & $28,18 \mathrm{Ca}$ & $32,64 \mathrm{Ba}$ & $35,03 \mathrm{Aa}$ \\
\hline
\end{tabular}

Same capital letters in the lines and lower case letters in the columns do not differ by logistic regression at $5 \%$ significance level.

The milk composition of crossbred cows had higher contents of protein and lactose $(\mathrm{p}<0.001)$, but the fat level was non-significant ( $\mathrm{p}>0.05)$. Just as for lactose and protein contents $(\mathrm{p}<0.01)$, crossbreds were superior to purebreds in solid yields $(\mathrm{p}<0.05)$. Conversely, crossbred cows presented a better mammary gland health if compared to purebred ones, which can be observed by their SCS $(\mathrm{p}<0.0001)$.

The Wood lactation curves (Figure 1, A, B and C) demonstrates in a graphically form the results of the interaction between genetic group and parity (Tables 1 and 2) among the lactation, with a yield rise in multiparous cows. From the third calving onwards, crossbreds produced more milk than did purebreds along all lactation, however, in the first and second lactation, both genetic groups had no difference between each other. Cows with more than one parity reached peak lactation between 50 and 60 days in milk (DIM), while primiparous did it nearly 80 DIM for purebreds and around 100 DIM for crossbreds.

The Wood lactation curves for fat and protein contents (Figure $2 \mathrm{~B}$ and $\mathrm{C}$ ) showed that both were higher in early lactation and decreased around 5060 DIM, and then show a slight increase until the end of lactation. Differently, purebred superiority in terms of SCS (Table 1) was evident over the entire lactation, with lower values at early lactation for both genetic groups (Figure $2 \mathrm{D}$ ), reversely to what was for lactose content (Figure $2 \mathrm{C}$ ). 
The genetic group had no influence on calf and heifer live weights (Figure 3), with initial and final measures of 46.9 and $496.1 \mathrm{~kg}$ for Holstein cows and of 45.8 and $480.7 \mathrm{~kg}$ for Holstein x Simmental animals.

Figure 1. Nonlinear curve of milk yield for cows with one (A) two (B) or three and more parities (C) according to days in milk (DIM), for Holstein purebred (-) and Holstein x Simmental crossbred cows (- - -).
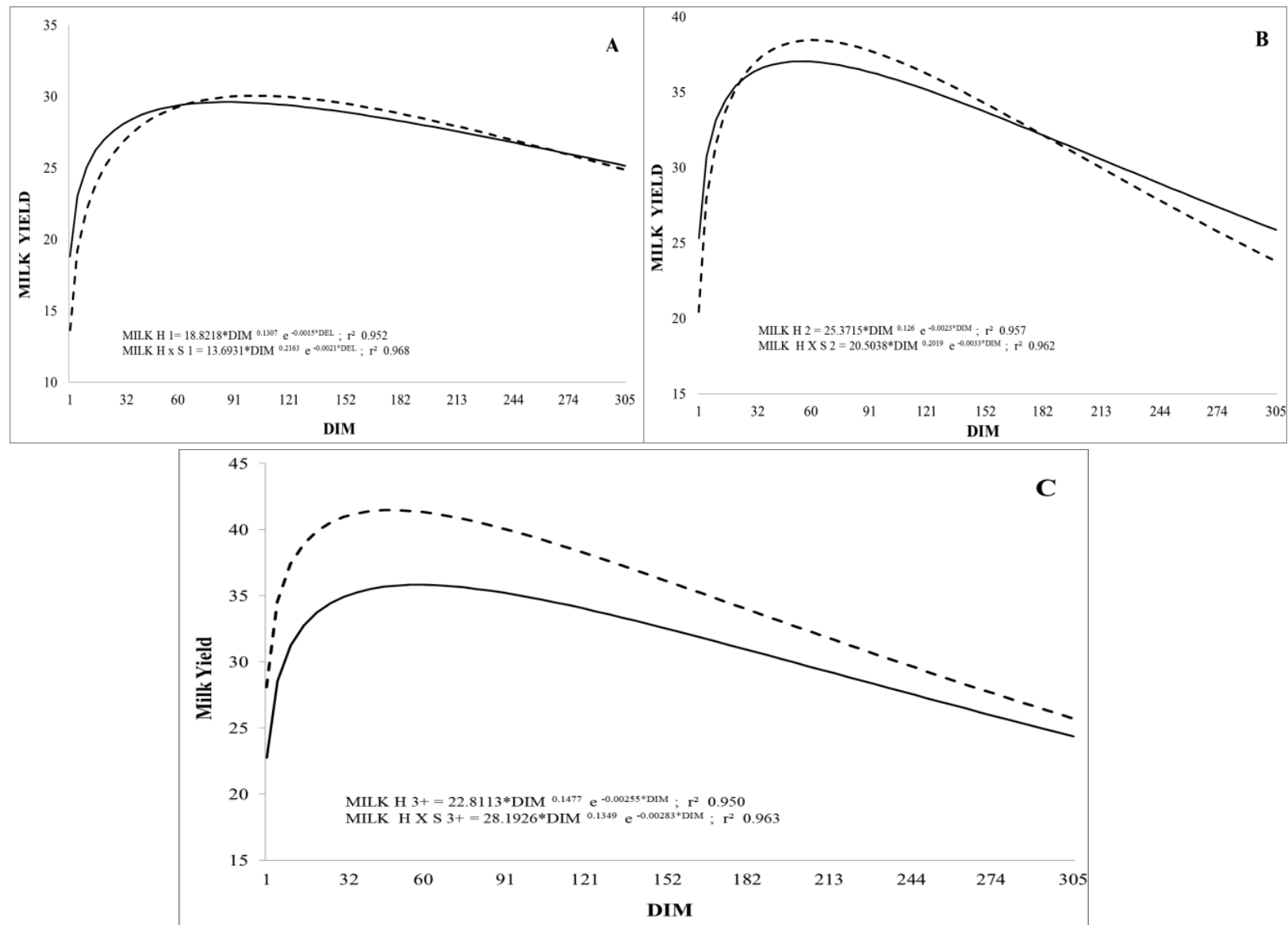
Figure 2. Nonlinear curve of protein (A), fat (B), lactose (C), and somatic cell score (SCS) (D) according to days in milk (DIM), for Holstein (- $)$ and crossbred Holstein x Simmental cows (- - -).

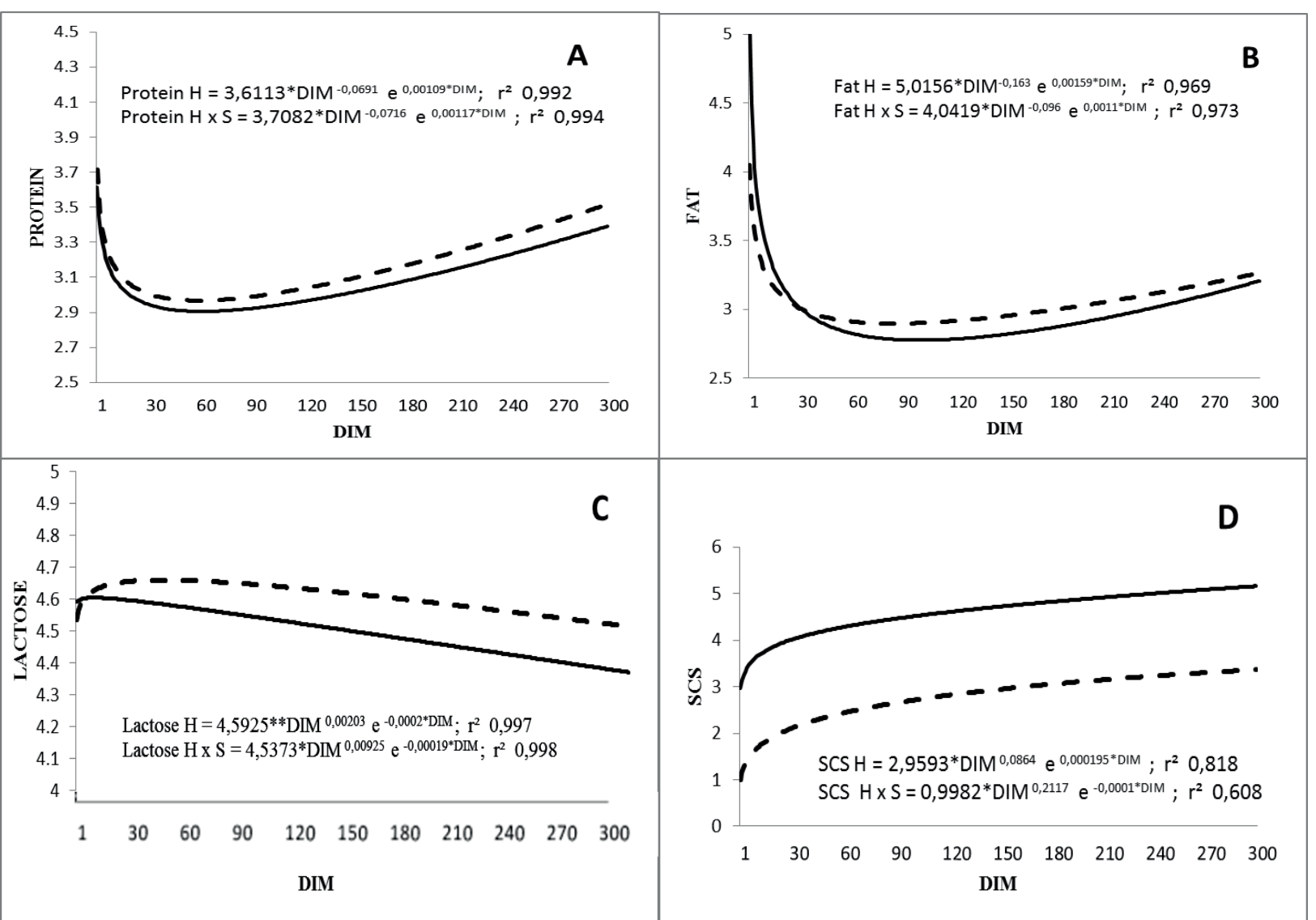

Figure 3. Nonlinear growth curve for Holstein (-) and Holstein x Simmental (- - -) heifers and calves.

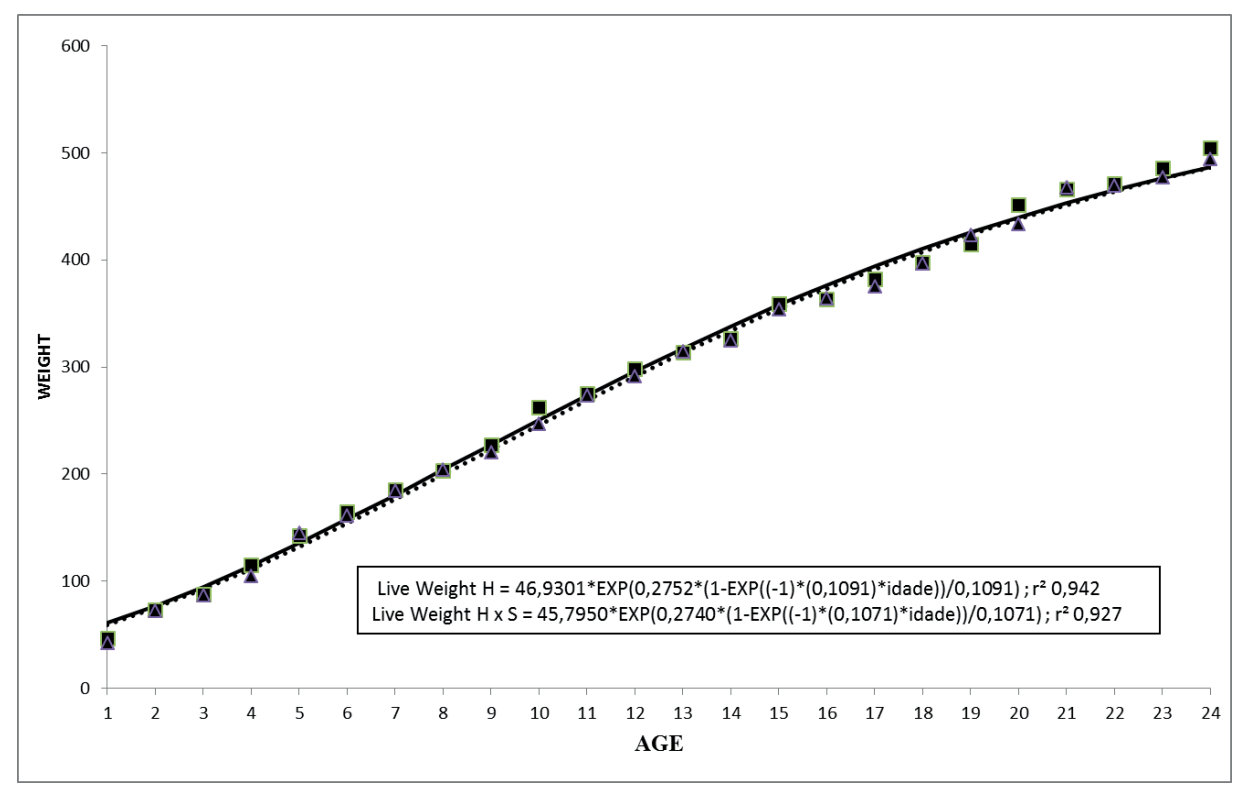

- Monthly average values observed for Holstein heifers and calves

A Monthly average values observed for Holstein x Simmental heifers and calves. 


\section{Discussion}

The higher ECM in all lactations and milk yields in the third or more lactations for crossbred Holstein x Simmental cows (in Table 1, Table 2 and Figure 1) have no support in the literature. By contrast, some reports have shown that Holstein x Simmental crossbred cows tend to yield less milk than Holstein purebreds (BRÄHMIG, 2011), with values between 92 and $95 \%$ of the total production of Holstein cows, or no differences between the genetic groups (SCHWAIGER, 2008). Similar results are also reported for other crossbreds such as Holstein $\mathrm{x}$ Montbeliarde cows, showing milk yields lower than or equal to those of Holstein cows (DE HAAS et al., 2013; HAZEL et al., 2013, 2014; MALCHIODI et al., 2014). In this study, the higher energy corrected milk yield of crossbred cows and for uncorrected milk yield in crossbred cows with three or more lactations may be related to the lower values of SCS (2.93 vs. 4.49 respectively; Table 1 ). This outcome can be related to the Simmental breed used in the crossing, which presents a lower SCS compared to Holstein cows (BRÄHMIG, 2011). The SCS is an indicator of subclinical mastitis. The negative effects of mastitis on milk yield are mainly due to lesions in the mammary gland secretory epithelium, reducing milk synthesis and secretion (LEITNER et al., 2011; BRÄHMIG, 2011; MALCHIODI et al., 2014; CINAR et al., 2015). The negative effect of SCS on milk yield is more evident in cows with more parities (RUEGG; PANTOJA, 2013), which also can be observed in our results, where Holstein cows with 3 or more parities produce less milk than the crossbred ones (Table2). Such a negative impact can be affirmed by the statistical analysis of milk data with less than 200.000 cells/ ml SCC, which showed no difference between the genetic groups $(32.24 \pm 0.43$ for purebred Holstein cows and $31.88 \pm 0.56$ for crossbred Holstein x Simental cows; $\mathrm{P}=0.5837$ ). Interestingly, when analyzing these dataset, the average yield of Holstein cows increased while that of crossbred cows did not.
Similarly, the higher SCS of Holstein cows can explain the greater lactose content for crossbred Holstein x Simmental cows (Table 1) (ALESSIO et al., 2016) since there is no evidence for differences between these genetic groups, in terms of lactose content registered in the literature. High SCS in milk changes the alveolar permeability allowing a greater passage of lactose from mammary gland into the bloodstream, as well as reduces lactose synthesis as a result of lesions in the secretory epithelium (WICKSTRÖM et al., 2009; FORSBÄCK et al., 2010). In addition to the above-mentioned factors, the lactose is also used as a food source by pathogens within the infected mammary gland (BLUM et al., 2008). Lactose is the milk component with the highest osmotic capacity, being responsible for the total milk yield, thus, its reduced content explains the lower milk yield of Holstein cows (GHASEMI et al., 2013; CINAR et al., 2015), as well as for ECM and protein content.

In addition, higher protein content and yield were observed in the milk of crossbred cows (Holstein x Simmental). This better performance can be explained by the heterosis effect for these traits. Despite being low for milk composition, heterosis effect had a positive effect on protein content for Holstein $\mathrm{x}$. Simmental crossbreds in other studies (SCHWAIGER, 2008; BRÄHMIG, 2011). Nonetheless, for this variable, genetic complementarity between breeds might not have been the main reason for such advantage to crossbred cows, as other studies have no reported differences between Holstein and purebred Simmental cows (KOÇ, 2011; KUCZYŃSKA et al., 2012; PICCAND et al., 2013). In our research, protein content and yield remained higher for crossbreds when only data on cows with SCS lower than 200.000 cells $/ \mathrm{ml}$ were analyzed.

Another reason for the higher milk yield of crossbred cows can be their larger body condition score (BCS) range, being 3.63 against 2.94 for purebreds (KNOB et al., 2016). Cows that lose 
more BCS have greater risks of metabolic diseases, especially in early lactation, which also impact on milk yield. Hence, having more body reserves to extract nutrients during negative energy balance (NEB) at lactation peak (ROCHE et al., 2009) crossbreeds cows present less negative impacts of NEB on milk yield.

The similar growth rates of calves and heifers in both genetic groups (Figure 3) corroborate the results found in the literature (BRÄHMIG, 2011; SCHWAIGER, 2008). This pattern may arise from the breed characteristics of Holstein and Simmental, which are both of European origin (Bos taurus) and referred to as major breeds, with similar growth and sexual maturity traits. Brown et al. (2001) reported similar results in evaluations of growth and weight gain for crossbred heifers from other large breeds, such as Holstein $\mathrm{x}$ Brown Swiss compared to Holstein. To further strengthen this fact, we may also cite reports by Knob et al. (2016), who observed no difference in body weight between Holstein $\mathrm{x}$ Simental and Holstein adult cows, reaching 651.7 $\mathrm{kg}$ and $640.6 \mathrm{~kg}$, respectively. These findings may help to explain why there were no differences in the growth curves and weight gain of animals. It is, therefore, unlikely that the use of crossbred animals would delay the start of a productive life of cows, and no changes in the calf and heifer rearing will be needed if Holstein farmers decide to introduce a crossing system with Simmental.

\section{Conclusion}

In conclusion, crossbred Holstein x Simmental cows have higher milk yield as the Holstein ones. Crossbreeds cows produce milk with better quality, indicated by lower SCS and higher solids content. These animals show similar growth, without delaying the start of a productive life of dairy cows in subtropical environment.

\section{Acknowledgements}

We would like to thank the dairy farmer that kindly collaborated in this research, as well as to the FAPESC and the CAPES for Master scholarship to the first author.

\section{References}

ALESSIO, D. R. M.; THALER NETO, A.; VELHO, J. P.; PEREIRA, I. B.; MIQUELLUTI, D. J.; KNOB, D. A.; SILVA, C. G. Multivariate analysis of the lactose content of Holstein and Jersey cows. Semina. Ciências Agrárias, Londrina, v. 37, n. 4, p. 2641-2652, 2016.

BLUM, S.; HELLER, E. D.; KRIFUCKS, O.; SELA, S.; HAMMER-MUNTZ, O.; LEITNER, G. Identification of a bovine mastitis Escherichia coli subset. Veterinary Microbiology, Barcelona, v. 132, n. 1-2, p. 135-148, 2008.

BRÄHMIG, J. Einfluss der wechselkreuzung von deutschen Holsteins und Deutschem Fleckvieh auf milchleistung und milchqualität in einem automatischen melksystem. 2011. Thesis (Tiermedizinische Doktor) Ludwig Maximilians Universität, München.

BROWN, A. H.; COBLENTZ, W. K.; SANDELIN, B. A.; LESMEISTER, K. E. Growth, Luteal activity, and pregnancy rates of three breed types of dairy heifers in a forage-based development program 1. The Professional Animal Scientist, Champaign, v. 17, n. 6, p. 20-26, 2001.

CINAR, M.; SERBESTER, U.; AYHAN, C.; MURAT, G. Effect of somatic cell count on milk yield and composition of first and second lactation dairy cows. Italian Journal of Animal Science, London, v. 14, n. 1, p. 105-108, 2015.

DE HAAS, Y.; SMOLDERS, E. A. A.; HOORNEMAN, J. N.; NAUTA, W. J.; VEERKAMP, R. F. Suitability of cross-bred cows for organic farms based on crossbreeding effects on production and functional traits. Animal, Cambridge, v. 7, n. 4, p. 655-664, 2013.

FORSBÄCK, L.; LINDMARK-MÅNSSON, H.; ANDRÉN, A.; AKERSTEDT, M.; ANDRÉE, L.; SVENNERSTEN-SJAUNJA, K. Day-to-day variation in milk yield and milk composition at the udder-quarter level. Journal of Dairy Science, Champaign, v. 93, n. 8, p. 3569-3577, 2010.

GHASEMI, Z.; ASLAMINEJAD, A. A.; TAHMOORESPUR, M.; ROKOUEI, M.; AROUGH, F. Association of somatic cell score with production traits in iranian holstein cows. Iranian Journal of Applied Animal Science, Rasht, v. 3, n. 3, p. 491-495, 2013. 
HAZEL, A. R.; HEINS, B. J.; SEYKORA, A. J.; HANSEN, L. B. Montbéliarde-sired crossbreds compared with pure Holsteins for dry matter intake, production, and body traits during the first 150 days of first lactation. Journal of Dairy Science, Champaign, v. 96, n. 3, p. 1915-23, 2013.

Production, fertility, survival, and body measurements of Montbéliarde-sired crossbreds compared with pure Holsteins during their first 5 lactations. Journal of Dairy Science, Champaign, v. 97, n. 4, p. 2512-2525, 2014.

HEINRICHS, A. J.; ROGERS, G. W.; COOPER, J. B. Predicting body weight and wither height in Holstein heifers using body measurements. Journal of Dairy Science, Champaign, v. 75, n. 12, p. 3576-3581, 1992.

KNOB, D. A.; ALESSIO, D. R. M.; THALER NETO, A.; MOZZAQUATRO, F. D. Reproductive performance and survival of Holstein and Holstein x Simmental crossbred cows. Tropical Animal Health and Production, Heidelberg, v. 48, n. 7, p. 1409-1413, 2016.

KOÇ, A. A study of the reproductive performance, milk yield, milk constituents, and somatic cell count of Holstein-Friesian and Montbeliarde cows. Turkish. Journal of Veterinary and Animal. Sciences, Ankara, v. 35, n. 5, p. 295-302, 2011.

KUCZYŃSKA, B.; PUPPEL, K.; GOŁĘBIEWSKI, M.; KORDYASZ, M.; GRODZKI, H.; BRZOZOWSKI, P. Comparison of fat and protein fractions of milk constituents in Montbeliarde and Polish HolsteinFriesian cows from one farm in Poland. Acta Veterinaria Brno, Brno, v. 81, n. 2, p. 139-144, 2012.

LEITNER, G.; MERIN, U.; SILANIKOVE, N. Effects of glandular bacterial infection and stage of lactation on milk clotting parameters: comparison among cows, goats and sheep. International Dairy Journal, Edmonton, v. 21, n. 4, p. 279-285, 2011.

MALCHIODI, F.; CECCHINATO, A.; PENASA, M.; CIPOLAT-GOTET, C.; BITTANTE, G. Milk quality, coagulation properties, and curd firmness modeling of purebred Holsteins and first- and second-generation crossbred cows from Swedish Red, Montbéliarde, and Brown Swiss bulls. Journal of Dairy Science, Champaign, v. 97, n. 7, p. 4530-4541, 2014.

NEMES, Z.; ĐEDOVIĆ, R.; VIDOVIĆ, V.; ESZES, F.; GÁSPÁRDY, A. An example for the transit-heterosis in the non-return rate of upgraded dairy genotypes. Scientific Papers Animal Science and Biotechnologies, Timisoara, v. 45, n. 1, p. 215-219, 2012.
OLTENACU, P. A.; BROOM, D. M. The impact of genetic selection for increased milk yield on the welfare of dairy cows. Animal Welfare, South Mimms, v. 19, p. 39-49, 2010.

PEEL, M. C.; FINLAYSON, B. L.; MCMAHON, T. A. Updated world map of the Köppen-Geiger climate classification. Hydrology and Earth System Sciences, Göttingen, v. 11, n. 3, p. 1633-1644, 2007.

PICCAND, V.; CUTULLIC, E.; MEIER, S.; SCHORI, F.; KUNZ, P. L.; ROCHE, J. R.; THOMET, P. Production and reproduction of Fleckvieh, Brown Swiss, and 2 strains of Holstein-Friesian cows in a pasture-based, seasonal-calving dairy system. Journal of Dairy Science, Champaign, v. 96, n. 8, p. 5352-5363, 2013.

ROCHE, J. R.; FRIGGENS, N. C.; KAY, J. K.; FISHER, M. W.; STAFFORD, K. J.; BERRY, D. P. Invited review: body condition score and its association with dairy cow productivity, health, and welfare. Journal of Dairy Science, Champaign, v. 92, n. 12, p. 5769-5801, 2009.

RODRIGUES, R. S.; THALER NETO, A.; NODARI, L. F.; DAL, J. G.; LUIZ, A.; DIAS, G. Crescimento de novilhas mestiças das raças Holandesa e Jersey em comparação ao Holandês. Revista de Ciências Agroveterinárias, Lages, v. 13, n. 1, p. 14-22, 2014.

RUEGG, P. L.; PANTOJA, J. C. F. Understanding and using somatic cell counts to improve milk quality. Irish Journal of Agricultural and Food Research, Carlow, v. 52, n. 2, p. 101-117, 2013.

SAXTON, A. M. Genetic analysis of complex traits using SAS®. Cary: SAS Institute Inc., 2004. 292 p.

SCHWAIGER,V. Kreuzungszucht beim milchvieh - ein ausblickvor und nachteile der kreuzungszucht zwishen Deutchem Fleckvieh und Deutschen Holstein. 2008. Thesis (Tiermedizinische Doktor) - Ludwig Maximilians Universität, München.

THALER NETO, A.; RODRIGUES, R.; CÓRDOVA, H. Desempenho produtivo de vacas mestiças Holandês $\mathrm{x}$ Jersey em comparação ao Holandês. Revista de Ciências Agroveterinárias, Lages, v. 12, n. 1, p. 7-12, 2013.

WICKSTRÖM, E.; PERSSON-WALLER, K.; LINDMARK-MÅNSSON, H.; OSTENSSON， K.; STERNESJÖ, A. Relationship between somatic cell count, polymorphonuclear leucocyte count and quality parameters in bovine bulk tank milk. Journal of Dairy Research, Cambridge, v. 76, n. 2, p. 195-201, 2009. 